\title{
Contesting the International Criminal Court: Bashir, Kenyatta, and the Status of the Non-Impunity Norm in World Politics
}

\begin{abstract}
Adam Bower
This article is forthcoming in Journal of Global Security Studies (2019), DOI: 10.1093/jogss/ogy037. The copyright for this article is held by Oxford University Press.

Acknowledgements: Earlier versions of this article were presented at University College Dublin, University of St Andrews, European University Institute, University of Edinburgh, and University of Oxford, as well as workshops at Goethe University Frankfurt, the Peace Research Institute Frankfurt, and the 2016 International Studies Association Annual Convention. I wish to thank the organizers and attendees for their constructive engagement with the project. Special acknowledgement is owed to Andrea Birdsall, James Cross, Nicole Deitelhoff, Anthony Lang Jr., Mateja Peter, Jenna Sapiano, Anette Stimmer, Lisbeth Zimmerman, my colleagues on this special issue, the anonymous reviewers, and the editorial team at JoGSS for their valuable feedback that greatly improved this piece.
\end{abstract}

\begin{abstract}
The International Criminal Court (ICC) is the centrepiece of an expanding international norm of non-impunity, which holds that all individuals should be equally subject to accountability for atrocity crimes. Despite rapid institutional growth, the ICC faces a number of challenges, including enduring resistance to the prosecution of senior state officials. Over the past decade, a number of African states have attempted to suppress ICC cases against Sudanese President Omar al Bashir and Kenyan President Uhuru Kenyatta, and enshrine formal exemptions from ICC jurisdiction for sitting Heads of State. In this article, I focus on the dynamics and impact of contestation in a highly institutionalized environment. The ICC is embedded within a dense network of overlapping legal rules and norms and as a consequence, debates over its operation and legitimacy are primarily undertaken via the distinctive discourses and practices of international law. I argue that despite often vociferous challenges, contestation surrounding Bashir and Kenyatta has not led to an erosion of the non-impunity norm because challenges have been largely conducted through modes of "applicatory contestation" that are less damaging to the foundational validity of the norm. Legalization has thus played a dual role, providing strategic justifications for attempts to narrow the scope of non-impunity, but also empowering counter-contestation by pro-norm constituencies.
\end{abstract}




\section{Introduction}

Amidst a host of international norm-building initiatives in the late $20^{\text {th }}$ and early $21^{\text {st }}$ centuries, the emergence of the International Criminal Court (ICC) is among the most ambitious in terms of its prospective scale and scope. The ICC is the first permanent international court dedicated to the investigation and prosecution of mass atrocity crimes, and is the centerpiece of an expanding global effort to end impunity for grave violations of human rights and international humanitarian law (Sikkink 2011). Yet the ICC appears to be facing an uncertain future. Its first fifteen years of existence have been characterized by substantial institutional growth but also mounting concerns regarding the geographic distribution and concomitant fairness of its case selection, problems with the process and outcomes of investigations and trials, and resource constraints tied to ambivalent state support for the Court's budget and operations (Bosco 2014; Stahn 2015; Tiemessen 2014). Amidst these challenges, one persistent dispute concerns the ability of an international court to assert authority over Heads of State and senior state officials. This feature of ICC jurisdiction strikes to the heart of state sovereignty and represents an especially costly transfer of national authority to a supranational institution.

In this light, the criminal proceedings against Sudanese President Omar Hassan al Bashir and Kenyan President Uhuru Muigai Kenyatta and Deputy President William Ruto represent especially valuable instances by which to evaluate the evolution of the ICC's global authority, and by extension the status of the non-impunity norm in world politics. United Nations Security Council Resolution 1593 (2005), which referred the conflict in Darfur to the ICC Prosecutor, was made possible by the acquiescence of the three permanent UNSC members that are not parties to the Rome Statute, reversing their prior resistance to the new global court. The Kenyan situation was, by contrast, the first occasion in which the ICC Prosecutor employed his proprio motu authority to initiate an investigation without state direction. The ensuing indictments are also rare instances where the highest leaders of the state are targeted for their alleged role in atrocities. Subsequent developments have highlighted important questions concerning the status of the Court and the international commitment to ending impunity. While concerns had already begun to emerge, the Bashir indictment provided the impetus for a much more concerted and aggressive policy of contestation by a number of African states and the African Union. These actors have sought to limit the scope of ICC authority by suppressing the cases against Bashir and Kenyatta, and using these specific processes to highlight more fundamental critiques of the ICC's global justice project. This has further involved refusals to cooperate with the ICC proceedings, placing these states in 
violation of UN Security Council resolutions and, in the case of ICC State Parties, their obligations under the Rome Statute.

Is such contestation a fundamental threat to the legitimacy of the ICC and its norm of non-impunity, or a natural if unwelcome consequence of deepening engagement with international norms and hence evidence of the norm's resiliency? More broadly, what can these experiences illustrate about the processes through which norms are strengthened, weakened, and potentially transformed? A number of studies have examined the reception, implementation, and contestation of international human rights and criminal law norms by African governments, state institutions, and civil society (Clarke, Knottnerus, and Volder 2016; du Plessis 2010; Jalloh and Bantekas 2017; Murungu and Biegon 2011). Yet amongst this impressive literature there has been less consideration for how these actors have shaped norms through their interventions (Mills and Bloomfield 2018). The present article does not aim to catalogue all challenges facing the ICC but instead employs the Bashir and Kenyatta cases as a lens through which to examine the process and impact of contestation surrounding the Court. ${ }^{1}$ In addition to their individual importance, these episodes are emblematic of broader disputes concerning the nature of the contemporary international criminal justice regime as embodied in the ICC.

Yet despite its public and often vociferous nature, I argue that contestation concerning Bashir and Kenyatta has stalled the further expansion of the non-impunity norm but has not as yet precipitated its erosion. In making this case I highlight two potential trajectories for norm change, following the framework of this special issue. Claims that the ICC's operations reflect the deep-seated racism and bias of the contemporary international order are employed by some African governments to promote alternatives to the expectation of supranational criminal accountability in response to atrocity - in effect disputing the legitimacy of non-impunity norm as currently constituted. Yet these forms of "validity contestation" have enjoyed little endorsement outside of the region, and no actors openly deny that individuals should be held accountable for heinous international crimes. Consequently, in diplomatic settings "applicatory contestation" has dominated as contesting actors have strategically attempted to narrow the conditions under which the non-impunity norm can be enacted. As such, the operationalization of an international justice mandate remains under considerable dispute; the rapid rise of a

\footnotetext{
${ }^{1}$ This article does not directly consider more technical critiques of the ICC's performance with respect to case selection, investigation procedures, trial strategy, and the legal merits of specific judgements. Interested readers are encouraged to consult the burgeoning studies in leading international law journals. For a consideration of the international criminal accountability norm in wider perspective, please see the article by Jo and Simmons in this issue.
} 
universalistic conception has not displaced a contrary view that regards some exceptions as pragmatic. But forms of applicatory contestation have also met with resistance and I conclude that the limited official acceptance of contesting claims has thus far been insufficient to generate formal changes to the norm. Instead, persistent non-compliance with ICC requests and an associated lack of enforcement by the international community provides the most likely pathway towards a de facto alteration of the non-impunity norm that accepts an exemption for senior state officials under some limited circumstances.

In explaining the uneasy endurance of the non-impunity norm, this article sheds additional light on both actor- and structure-related conjectures advanced by Zimmerman and Deitelhoff in their framework article. On the one hand, the findings support the assertion that diversity is important in sustaining international norms: the coalition of actors seeking to modify the non-impunity norm is relatively limited in absolute numbers and regionally focused, as it is primarily composed of sub-Saharan African states. By contrast, the constituency of actors opposing these efforts are more numerous, comprise a broader crosssection of states and non-state actors, and include materially powerful actors such as European states and-somewhat surprisingly - the United States. This support, however, is largely rhetorical and has not included active measures to bolster ICC authority, a fact that has substantially impeded the ICC's enforcement capacity. On the other hand, this study confirms expectations that institutionalization - and especially legalization-helps to bolster norms against erosion or replacement. The ICC is deeply embedded within a complex network of overlapping norms, rules, and practices and international law thus serves as a primary language through which actors discuss the Court and the non-impunity norm. These structures provide multiple and at times contradictory resources through which actors may articulate more specific claims, by positioning sovereignty and non-interference in contradistinction to the universal application of international accountability. Institutionalization has therefore played a dual role in both providing logics for challenging non-impunity, but also in facilitating efforts by states, transnational civil society, and the Court itself to counter attacks and bolster normative validity. Echoing the argument developed by Brunnée and Toope (this issue), I suggest that the latter effort of norm reinforcement has won-out largely because the structure of legal argumentation has focused much of the claim-making on the comparatively less damaging terrain of the norm's application. 


\section{The ICC and the structure of the non-impunity norm in world politics}

Three generic features of the non-impunity norm can be identified. First, the norm applies to a discrete set of acts - genocide, crimes against humanity, war crimes, and aggression - that are regarded as especially egregious forms of violence and thus to be classified as crimes of international concern. The particular severity of these crimes means that they can never be justified as legitimate state acts. Hence a second feature of the non-impunity norm is its encapsulation of a fundamental shift—-begun after World War II but gaining momentum in the 1980s - from states to individual human beings as primary subjects of international criminal law. In this respect, the non-impunity norm is ostensibly universal in its application, insofar as it is supposed to apply to all human beings regardless of their role or status. Third, the norm is underpinned by an assumption that regularized criminal proceedings in the form of transparent and fair trials are the appropriate mechanism for addressing alleged acts of atrocity (Drumbl 2007).

Of key concern is who may be the subject of criminal scrutiny and how international accountability may be pursued and enacted. Article 27(1) of the Rome Statute reaffirms the position of previous international criminal tribunals that its legal remit "shall apply equally to all persons without any distinction based on official capacity," thereby removing the established customary legal protections that granted Heads of State and other senior officials immunity from prosecution at international courts. This applies most directly to nationals of ICC State Parties, with ratification of the Rome Statute constituting a pre-emptive waiver of immunity. In this respect the ICC can be viewed as part of a larger trend towards holding state leaders accountable for past crimes in both national and international courts - a phenomenon that has occurred only sporadically and typically once the persons in question have left their official roles. ${ }^{2}$ The ICC is particularly controversial because it allows for the prosecution of actors while they remain in office. This innovation brings the Court into potential conflict with the wider international legal order, as immunities endure outside of the jurisdictional context of specific treaties (Schabas 2017, 61-65). In recognition of this fact, Article 98 of the Rome Statute accommodates established international obligations concerning forms of diplomatic immunity between states. ICC non-parties thus possess no obligation to cooperate with the Court, while ICC member states would still be required to observe immunities for nationals of

\footnotetext{
${ }^{2}$ As with the prosecution Nazi and Japanese leaders after World War II; domestic trials in Argentina, Bolivia, Chile, El Salvador, Greece, Guatemala, Peru, and Portugal among others; and international and hybrid tribunals for Cambodia, Chad (Senegal), the Former Yugoslavia, Sierra Leone, and Rwanda.
} 
non-party states in their bilateral dealings. The Bashir indictment has brought this particular concern most clearly to the fore (Akande 2009; Gaeta 2009).

The ICC is an independent legal entity that can operate autonomously from state approval conditional on a set of constraints. The ICC is not a part of the United Nations system but is still subject to Security Council influence in the form of the UNSC's referral power and its ability to suspend ongoing ICC proceedings on a renewable one-year basis in the interests of international peace and security (Article 16). In its relationship with states, the Court's powers are delimited by procedural checks and balances and ordered by a principle of complementarity wherein the Court will only intervene where national authorities are judged to be unable or unwilling to act (Article 17). States thus retain the primary responsibility for investigating and prosecuting atrocity crimes, but their actions are evaluated in light of negotiated criminal justice standards enshrined in the Rome Statute and with the oversight of a supranational court. Finally, since the Court does not possess its own police force, the enforcement of international criminal law relies on the active assistance of states including by arresting and surrendering suspects, facilitating access to evidence and witnesses, and financing the Court's activities. This is a primary means by which states have enabled and impeded the ICC's pursuit of accountability.

\section{Contestation and norm change}

Norms are subject to continual processes of interpretation and change. The construction of social life can imply the iterative affirmative development of norms but equally involves attempts to dispute, question, and re-configure these collective understandings. Contestation is thus an inherent feature of diplomacy and may even be regarded as vital for a genuinely pluralistic international society (Wiener 2008). Hence contestation does not uniformly indicate the decay of a norm and its potential replacement by an alternative and can in some circumstances lead to the strengthening of the existing standard.

\section{Institutionalization and contestation}

In keeping with a central conjecture of this special issue, the institutionalization of the nonimpunity norm is an important factor in explaining its operation and status. The norm has been extensively established in a series of domestic, regional, and international legal structures - of which the ICC is an especially prominent example - and further embedded within dense overlapping sets of norms, rules, and practices concerning substantive issue areas such as human rights, international humanitarian law, criminal law, and aspects of political order 
including notably sovereignty and non-interference (Jo and Simmons, this issue). As a consequence, contestation surrounding the non-impunity norm plays out in a highly legalized environment which profoundly shapes the ways in which the norm may be described and adjudicated (Brunnée and Toope, this issue).

The assertion that international law serves as a primary source of legitimate authority in the international system is widely accepted among legal scholars and practitioners. Within International Relations, constructivists have been most explicit in identifying the constitutive role of international law as a dominant mode for framing conceptions of appropriate behavior and advancing claims in the international system (Bower 2017; Brunnée and Toope 2010; Reus-Smit 2004). From this perspective, law is characterized by its particular form of principled justification and internal processes of generation and development—what Brunnée and Toope (2010) refer to as the "practice of legality."

Both norms and laws articulate standards of behavior, but the shift to a legal form matters to the development of norms in two ways. On the one hand, legalization provides greater specification concerning the scope of a norm (what it includes and excludes) and an institutionalized forum delineated by the practices of legality through which norms can be assessed and potentially revised. In the present case, the Rome Statute and associated legal rules have served as focal points in discursive interventions both seeking to challenge and uphold the non-impunity norm. On the other hand, the shift into a legal domain is associated with a change in the acceptable forms of argumentation, as political, economic, and ethical rationales are superseded by technical assessments concerning the meaning and limits of rules. Scott (1994) has characterized this as the "ideology" of international law where, despite the irrepressible intrusion of power, claims advanced through the distinctive language and practices of law represent a superior basis for action as compared with other potential justifications.

This does not mean that institutionalization automatically leads to the strengthening of norms, however, as the contemporary international legal system provides a repertoire of ideas that actors can employ to support or challenge norms. For both contesting and status-quo actors, the diplomatic context necessitates the adoption of claims referencing the Rome Statute and wider international legal environment in which it is embedded. This, in turn, has tended to reify legal discourses and practices that emphasize forms of applicatory contestation which hold more limited implications for the robustness of the norm. 


\section{Pathways of norm change}

The non-impunity norm as enshrined in the Rome Statute is directive in nature, in that it requires actors to undertake proactive efforts to investigate and prosecute atrocity crimes within their domestic courts, and to comply with requests for assistance from the ICC itself. Its emergence can therefore be characterized as a widening of accountability that involves the replacement of a prior proscriptive norm that excluded international criminal sanction and specifically exempted senior state officials from scrutiny. This process is incomplete and contains the potential for further change.

Forms of validity contestation deny the legitimacy of the non-impunity norm. Most provocatively, some African governments portray the ICC as discriminatory and an artefact of geopolitical inequality, suggesting that the international criminal justice regime is fundamentally untenable (du Plessis 2010, 19-67). More nuanced challenges are found in calls for states to be accorded greater autonomy in pursuing policies that do not conform to a hegemonic conception of international justice - for example by allowing alternatives to criminal prosecution such as political settlements, amnesties, and truth commissions. Successful validity contestation would see the substantial erosion of the non-impunity norm and its replacement by either a permissive norm that allows a wider array of non-criminal approaches to mass atrocity or a prohibitionary norm that explicitly forbids international judicial intervention.

The strategies of contesting actors are multifaceted and have involved a set of parallel claims that question whether the ICC's non-impunity standard is appropriate in all circumstances. Here the challenges have sought to limit the norm's reach by suggesting specific conditions under which criminal sanction should be de-emphasized either for a period of time or in relation to some particular class of actors. These forms of applicatory contestation offer a more plausible means of challenging ICC authority, I suggest, because they have been conducted through the recognized legal procedures of the Rome Statute and broader standards of international law. In the short term, applicatory contestation does not necessarily weaken a target norm since the initiatives can serve to further clarify the norm's content and scope. Were this to endure, however, it would create a new permissive exception within the wider norm of non-impunity and thus constitute a modest but important weakening of the norm's universality. The decline of a directive norm holding that all individuals are equally subject to criminal accountability would at minimum imply the re-emergence of a norm exempting some categories of actors from prospective sanction. While not yet realized, this presents the most likely avenue for normative change emerging from the episodes under examination here. 


\section{Assessing contestation and norm robustness}

Following the framework paper, norm robustness can be conceptualized as varying with respect to facticity - the degree to which the norm serves as a guide for conduct - and validity - the extent of discursive acceptance of the norm's content. This parallels the approach of customary international law scholarship that addresses forms of consistent state practice and expressions of belief concerning the existence of a legal obligation (opinio juris) (Price 2006). Deitelhoff and Zimmerman (this issue) identify four main dimensions along which norm robustness may vary: institutionalization, compliance, concordance (intersubjective agreement regarding the legitimacy of a norm), and third-party reactions to norm violations. A comprehensive accounting of the nature and dynamics of norm robustness thus requires an integration of behavioral and discursive indicators - what actors do and how they describe and justify their actions, and the responses these actions elicit from the wider international community-and how these features interact over time. No definitive formula can be determined ex ante; an assessment of a norm's status always involves interpretation and a relative weighting of behavioral and discursive factors, as captured in Kirgis' (1987) famous assertion that customary legal norms exist on a "sliding scale."

Jo and Simmons (this issue) argue for a "diversity" approach to measuring norm adoption and resistance with respect to international criminal accountability, incorporating the actions and views not only of states and intergovernmental organizations but also transnational civil society, armed non-state actors, and the general public. This is an admirable corrective to an overly-narrow emphasis on state agency, though the relevance of different categories of actors will naturally vary depending on the specific context under consideration. Here I focus on one dimension of the broader international criminal law regime and examine the most consequential actors in these episodes: the African Union and key African states (especially Kenya, Sudan, and more recently South Africa) as contesting actors, as well as the responses from other states, transnational and domestic civil society, and the International Criminal Court itself. Given their prominence as rare instances where Heads of State have faced international criminal investigation while in office, the ICC processes against Bashir and Kenyatta have generated specific behaviors as well as a high volume of public discourse which explicitly relates to the status of the non-impunity norm and its potential limits. In tracing the deployment and impact of contestation over the past decade, I draw on diplomatic statements, the records 
of relevant United Nations Security Council meetings, ICC documents, news reports, and interventions from civil society groups. ${ }^{3}$

As expressions of collective understandings, norms may sustain some degree of nonconformity before declining into irrelevance: universal adherence is not required for a norm to exist and influence actor conduct. Where behavior regularly diverges from the requirements of the norm, forms of discursive evidence - supporting the existing norm versus endorsing an alternative standard-become increasingly critical to an assessment of norm status as they contextualize the reasons for observed behavior (Kirgis 1987, 149). Moments of apparent crisis are thus especially valuable for assessing norm robustness since they reveal gaps and contradictions in the interpretation of a social standard. Violations provide an opportunity for alleged transgressors to publicly challenge a norm and articulate a new conception of appropriate behavior, and equally for other actors to identify and discipline deviations and thereby reinforce prevailing intersubjective expectations. Non-compliance that receives little or no condemnation would suggest a weakening norm, especially in cases where actors demonstrate a willingness to recognize the proposed changes. Alternatively, violations that elicit a more fulsome response could fairly be interpreted as indicating a resilient - if not strengthening-norm.

\section{Contesting the Court: Bashir and Kenyatta}

\section{The expansion of the non-impunity norm}

The idea of criminal accountability for acts of atrocity has diffused rapidly in domestic, regional, and international jurisdictions over the past 40 years, marking what Sikkink has termed a "justice cascade" in world politics (Sikkink 2011). 123 states have joined the Rome Statute $^{4}$, and state discourse evidences widespread support for the objectives of international justice amongst member states and-perhaps more surprisingly-non-parties like China, Russia, and the United States (Bower 2017, 127-31, 154-55). African states were early supporters of the ICC and were extensively involved in its drafting (Vilmer 2016, 1335-38). The AU encompasses both ICC members ${ }^{5}$ and non-parties, as well as a range of domestic regime types and historical experiences. The AU initially advocated for universal African membership in the Court (du Plessis 2010, 5-11; Mills 2012, 405), and has repeatedly stated

\footnotetext{
${ }^{3}$ Due to space constraints I identify only a limited number of representative statements, rather than seeking to catalogue all available expressions of critique or support.

${ }^{4}$ As of August 2018. This figure includes the recent withdrawal of Burundi.

${ }^{5}$ At present, 33 African states are ICC members.
} 
its "commitment... to the fight against impunity in accordance with the Constitutive Act of the African Union" even in the midst of its challenges that are the subject of this study (Assembly of the African Union 2016b, para. 2.i). The association of the ICC with an international consensus against impunity goes deeper than state structures, however, and is also seen in the extensive engagement of domestic civil society groups in the development of international criminal law norms and favorable public opinion polling in many countries including those currently experiencing ICC investigations and prosecutions. In these respects, the nonimpunity norm seems to enjoy high validity amongst a wide cross-section of actors.

Yet this apparent consensus regarding the goal of accountability can mask important disagreement over the implications of the anti-impunity norm in practice. Enthusiasm has often given way to hostility when state interests are adversely impacted by supra-national intervention. The decision by the governments of Uganda, Democratic Republic of the Congo, Central African Republic, Côte D'Ivoire, Mail, and Palestine to refer themselves to the ICC is indicative of this ambivalence: while presented as a willingness to submit to international legal scrutiny, these developments can equally be viewed as part of a strategy to instrumentalize international justice by targeting government opponents (Tiemessen 2014). The initiation of ICC processes against state agents has altered this dynamic and precipitated profound challenges directed against the Court. One might therefore fairly regard discursive endorsement as "cheap talk" that provides little evidence of norm strength. But while state views are complex and public expressions of support are not sufficient in isolation, neither are they costfree. Rather, contestation has played out in public and has enabled forms of countercontestation that have constrained state policy and moderated the negative impact on the nonimpunity norm.

\section{Emerging resistance}

On 31 March 2005 the Security Council, in response to a widely documented humanitarian crisis attributed to the actions of the Sudanese government and allied militias, passed Resolution 1593 in which it "refer[red] the situation in Darfur since 1 July 2002 to the Prosecutor of the International Criminal Court.” (United Nations Security Council 2005, para. $1)^{6}$ Resolution 1593 is significant in the context of the non-impunity norm both because it was the first time that the Security Council employed its referral power and because the

\footnotetext{
${ }^{6}$ Resolution 1593 passed with 11 affirmative votes, with Algeria, Brazil, China, and the United States abstaining.
} 
explanations associated with the vote, including among ICC non-parties, clearly associate the ICC with the cause of ensuring accountability for international crimes (Bower 2017, 154-55, 159-62). Yet the contribution to the norm's expansion is less apparent. Resolution 1593 explicitly exempted the nationals of non-party states other than Sudan from ICC jurisdiction (United Nations Security Council 2005, para. 6) and provided no mechanism for enforcing state cooperation nor any UN funds to support investigations stemming from the referral.

The Kenyan situation provides an important example of a State Party seeking to challenge its obligations from within a legal institution. On 31 March 2010, the ICC Pre-Trial Chamber II approved the Prosecutor's request to open an investigation into widespread violence that followed disputed national elections in 2007-2008. As the basis for its authorization, the Court found that there had been a lack of substantive national judicial proceedings (ICC Pre-Trial Chamber II 2010, 69-73). A year later the Court issued summons to appear for Kenyatta, Ruto, and four other associates, in relation to their alleged responsibility for crimes against humanity. At the time, Kenyatta and Ruto were prominent domestic political figures; elections in 2013 elevated them to the Presidency and Vice-Presidency, respectively, bringing questions of diplomatic immunity to the fore (Kendall 2014). Initially, the Kenyan government signed a Memorandum of Understanding with the Court and Mr. Kenyatta and Mr. Ruto then voluntarily appeared in The Hague to answer their summonses. Amidst this apparent cooperation, however, Kenya has sought to employ Rome Statute rules to bypass ICC prosecutions. Kenya claimed that its own domestic reforms and ongoing investigations demonstrated sufficient legal capacity and political will and should be prioritized, and submitted a request for the Court to turn over all relevant evidence to facilitate national investigations (Republic of Kenya 2011). The Court rejected both of these requests (Appeals Chamber, International Criminal Court 2011), leading to a series of filings in which the Kenyan government challenged the pre-eminence of the ICC investigation. ${ }^{7}$

Both the ICC's judicial arm and Office of the Prosecutor determined that Sudan and Kenya had not undertaken genuine efforts of a sufficient scope and quality to meet the standard of complementarity and refused to cede jurisdiction to national courts. In this early phase, therefore, applicatory contestation did not result in the avoidance of ICC scrutiny. Rather, the invocation of Rome Statute rules provided the basis for the Court to retain jurisdiction with

\footnotetext{
${ }^{7}$ Official Court records are available at http://www.icccpi.int/en_menus/icc/situations\%20and\%20cases/situations/situation\%20icc\%200109/court\%20records/Pages/in dex.aspx.
} 
respect to Sudan and Kenya. In response to these setbacks, both states, and the AU as a regional body, expanded their critiques and moved to obstruct the ICC investigations.

The empirical record supports the view that contestation was precipitated by a specific concern for the legal exposure of political leaders. Interestingly, neither the AU nor its constituent member states voiced objections to the initial UNSC referral or the resulting initiation of a formal ICC investigation in Darfur. However, the ICC indictment of Sudanese President Omar al-Bashir for crimes against humanity and war crimes (2009) and genocide (2010) aroused immediate criticism. The subsequent criminal process against Kenyan President Kenyatta only reinforced this hostility, as the AU combined both indictments in its critiques from 2011 (Hobbs 2015; Vilmer 2016, 1321-22). Contesting actors have strategically leveraged these cases as a means of framing a wider set of complaints concerning the contemporary international criminal law regime.

\section{Validity contestation and its limitations}

One dimension has seen the deployment of anti-colonial discourse, with claims of inequality and racism used to attack the legitimacy of the ICC and, by extension, the international legal order (Vilmer 2016, 1321). The overwhelming focus of the Court's activity has been within Africa and this has generated complaints from the likes of Rwandan President Paul Kagame and former AU chairman Jean Ping that the ICC is merely an "imperial" tool of Western powers that is unfairly targeting and "bullying" African states (AFP 2008; Sudan Tribune 2010). The Sudanese ambassador to the United Nations similarly decried the initial Bashir arrest warrant as "a criminal move" that "amounts to an attempt at regime change." (Simons and Macfarquhar 2009) The broader context for these critiques is an enduring resistance to supra-national interference in the domestic affairs of the state, oriented around discourses of sovereignty as a foundational principle of the international legal system (Kendall 2014, 402-3). Opposition to ICC processes in Sudan and Kenya have therefore often served as means of expressing broader demands for autonomy that privilege local and regional responses to mass violence. An insistence that the ICC's monolithic requirement for criminal prosecution is at times inappropriate animates many of the more specific challenges examined below.

Due to their visceral nature, validity challenges capture attention and are difficult to rebut. However, while such complaints have endured and found some sympathetic audiences primarily on the African continent, there is little evidence that they have permeated elsewhere. Forms of validity contestation are more often designed for domestic and regional audiences and within these contexts they do appear to have negatively impacted the ICC's legitimacy 
amongst some communities (Knottnerus 2016). But these discourses have not been endorsed by external actors and have hardly featured in formal diplomacy at the Security Council and elsewhere; hence they have had only a marginal impact on the status of the non-impunity norm when conceived as a global social standard. As a consequence, contesting actors have sought alternative diplomatic avenues by which to challenge the Bashir and Kenyatta/Ruto indictments. Importantly, the international dimension of these efforts has been conducted through the language of international law as the AU and African states have sought to resist the application of non-impunity by invoking specific Rome Statute rules and highlighting ostensible tensions between the ICC and other features of the international legal system. This applicatory contestation has been more successful, as it has generated specific and sustained responses from the international community. But doing so has also focused debate on the terrain of international law and thereby narrowed the potential corrosive effect on the nonimpunity norm.

\section{Head of State immunity and state sovereignty}

As noted earlier, the Rome Statute eliminates individual exemptions from prosecution based on official role, but this innovation has been challenged by the AU on the grounds that it diverges from established customary international law "by which sitting Heads of State and other senior officials are granted immunities during their tenure in office" (Assembly of the African Union 2015, para. 7). Irrespective of its status as an ICC member state, the Kenyan government also maintains that "[a]s the Rome Statute is a treaty like any other it must be read within the framework of international law that confers immunity to sitting Heads of State and Governments." (Republic of Kenya 2013, 11) African states - through the AU and in their individual capacities - have consistently argued that the indictments of Bashir and Kenyatta impede the operation of the respective governments and constitute an unacceptable interference in the sovereign affairs of the state, as discussed below (Assembly of the African Union 2011, 2013). A number of ICC non-parties, the Russian Federation and China chief among them, have used these cases as an opportunity to reassert their view that Heads of State continue to enjoy protection from international criminal tribunals (Russian Federation 2014; People's Republic of China 2014).

These debates involve fundamental questions of international politics and law, and contesting agents have largely sought redress via reference to specific international legal practices and Rome Statute rules. With respect to Sudan, the AU has repeatedly invoked Article 98 of the Rome Statute, arguing that this provision recognizes "that the Statute is not capable 
of removing an immunity which international law grants to the officials of States that are not parties to the Rome Statute." (Assembly of the African Union 2012, para. 6) The AU and many of its constituent members thus maintain that states are not obliged to arrest and surrender Bashir to ICC custody - a claim that has featured centrally in debates over non-compliance.

To that end, the AU encouraged its members to agree to so-called "bilateral immunity agreements" in order to provide legal protections prohibiting the surrender of nationals from ICC non-party states - most obviously President Bashir-to the Court (Assembly of the African Union 2012, para. 7). This mirrors a diplomatic innovation initially developed by the Bush Administration as a means of exempting United States nationals from prospective ICC jurisdiction - an effort that faced considerable opposition, including from African states (Kelley 2007). The AU initiative is thus in part intended to highlight the hypocrisy of powerful Western states in calling for the arrest of a prominent non-party national while using identical practices to protect their own citizens from legal scrutiny. The international community has not, by and large, been receptive to another attempted instrumentalization of Article 98, especially in light of the hugely controversial experience with similar US efforts. Legal critiques of the original Bush administration policy - to the effect that bilateral immunity agreements violated the intent of the Rome Statute and would place ICC members in contravention of their obligations - thus resurfaced and provided a powerful resource for opposing a similar effort. There is no evidence that any such agreements have been concluded. With this avenue largely blocked, African states turned to two further forms of applicatory contestation, involving additional formalized exemptions and institutional renegotiation, respectively.

\section{Peace, security, and Article 16}

Mark Kersten has argued that "[w]hile the peace-justice debate resonates in quarters beyond the African continent, the fact that African states have been the primary theatre for ICC interventions means that African states and communities have had to grapple directly with the possible tensions between ICC accountability and conflict resolution.” (Kersten 2018, 19). In other settings - notably DRC and Uganda — there have been calls to abandon ICC proceedings in favor of non-judicial mechanisms. In the present context, the AU has repeatedly petitioned the UN Security Council to temporarily suspend the respective ICC proceedings against Bashir and Kenyatta/Ruto as permitted in Article 16 of the Rome Statute (Assembly of the African Union 2011, para. 6, 2013, paras. 10(ii, ix-xi); Jalloh, Akande, and Plessis 2011; Knottnerus 2016). This request has been presented as a means of addressing regional peace and stability 
while still respecting legal commitments to the Court. Affected governments claim that external legal processes impede the ability of senior officials to dispense their constitutional duties and constitute an interference in national-level efforts to ensure accountability and societal stability. The AU has on numerous occasions expressed its "deep concern" over the issuance of arrest warrants for President Bashir on the grounds that an ICC trial could unsettle the nascent peace process and lead to an escalation of violence in Darfur (African Union Peace and Security Council 2009, para. 2). With respect to Kenya, particular attention has been paid to the country's role as "a frontline state in the fight against terrorism at regional, continental and international levels" in the wake of the September 2013 Westgate Mall attack in Nairobi (Assembly of the African Union 2013, para. 6). Yet the AU has also been careful to acknowledge human rights abuses in both conflicts and reiterate its "unflinching commitment to combating impunity." (African Union Peace and Security Council 2009, para. 9) Rather than avoiding accountability, therefore, the Article 16 requests were said to reflect an appropriate sequencing of political and legal considerations and taking account of the Court's place in a wider international legal order characterized by the pre-eminence of the UN Charter.

The AU initiative was broadly popular among African states and received tentative support among a few members of the Security Council. Yet the UNSC refused to authorize the deferral requests in both instances: no formal discussion ever took place regarding Darfur, ${ }^{8}$ while a draft resolution on Kenya failed to attain sufficient votes (United Nations Security Council 2013). In opposing the efforts, permanent Security Council members like France, the United Kingdom, and the United States made frequent reference to principled concerns for accountability and the intent of the Rome Statute. In particular, pro-ICC arguments centered around an assertion that the legal processes against President Bashir and President Kenyatta did not constitute a threat to international peace and security necessary to warrant the invocation of Chapter VII as required by Article 16. Rather than considered separately and sequentially, justice and peace were held to be necessarily interactive and mutually reinforcing.

This diplomatic failure was received by many African states as a further demonstration of inherent double standards in international diplomacy. This reflects a deeply-felt sense that international institutions - most of all the UNSC - and powerful Western states do not respect

\footnotetext{
${ }^{8}$ The Security Council never formally considered a draft resolution suspending the Bashir arrest warrant but did address the issue indirectly in a series of meetings on the topic of Sudan. The two most relevant discussions are 4 December 2009 (S/PV.6230) and 5 June 2012 (S/PV.6778). Only two states supported deferral in each instance: Libya and Burkina Faso (2009) and Morocco and India (2012).
} 
the wishes of the continent, or the ability of African institutions to address regional challenges. ${ }^{9}$ Mills $(2012,425)$ has suggested that

many African leaders just wanted some sort of acknowledgement of their concerns and their standing as global leaders. If there had been evidence that their concerns were being taken seriously, it is possible that there would not have been as widespread support on the part of African ICC state parties as there was for this and ensuing actions.

Contestation on the terms of Article 16 thus proved a double-edged sword: framing the deferral requests in the language of Rome Statute rules provided grounds for challenging ICC jurisdiction under specific circumstances, but also offered rhetorical means for supporters of the indictments to resist efforts to limit the Court's reach. At the same time, the engagement of the Security Council broadened the debate by drawing in concerns for political stability, sovereignty, and fairness. These latter linkages appear to have been especially effective in solidifying AU critiques among some important African constituencies.

\section{Institutional re-negotiation: amendments to the Rome Statute and African Court}

In response to impediments at the UNSC, the AU has adopted additional forms of applicatory contestation aimed at clarifying and limiting ICC jurisdiction via amendments to the Rome Statute and African regional institutions. The AU has sought to modify Article 16 to permit the UN General Assembly to authorize deferrals of ICC investigations and trials in instances where the Security Council is unable or unwilling to act (Assembly of ICC States Parties 2014b, sec. V; Jalloh, Akande, and Plessis 2011, 26-37). This can be understood as an attempt to shift discussions of criminal accountability to a forum where African states enjoy comparatively greater decision-making power. Were the Assembly of States Parties to grant this power to the UNGA, this could lead to a significant expansion of the use of deferrals. Thus far, however, the initiative has not received the support of the ASP and there is little indication that the issue will be revisited in the foreseeable future.

A related proposal has sought to alter Article 27 so as to enshrine legal immunity while in office for leaders elected through recognized democratic processes (Assembly of ICC States Parties 2014b, sec. VI.B). To that end, both the Kenyan government and regional allies have specifically referenced the 2013 elections that brought Kenyatta and

\footnotetext{
${ }^{9}$ These sentiments were reiterated by a number of African states, notably Namibia, South Africa, Tanzania, and Uganda, at the Assembly of States Parties meeting that followed the aborted UN effort. Official statements are available at https://asp.icccpi.int/en_menus/asp/sessions/general\%20debate/Pages/GeneralDebate_15th_session.aspx.
} 
Ruto to office as evidence of the will of the Kenyan people, and have argued that democratically elected leaders "should be allowed to discharge their mandate and address the developmental challenges of their countries without the distractions... until the end of their tenure." (Federal Republic of Nigeria 2013) Within the ICC Assembly of States Parties Kenya has presented this initiative as a modest correction, rather than wholesale rejection, of the ICC immunities standard: "In particular, Kenya explained that the objective of their proposal was not to grant immunity to Heads of State, their deputies and persons acting or entitled to act as such, but only to 'pause' prosecutions during their term of office" (Assembly of ICC States Parties 2014a, para. 12).

In these ways, the AU and its members have sought to re-shape the criminal accountability norm by embedding the issue of Head of State immunity in future ASP discussions - thus far with little appreciable interest from other ICC members (Assembly of the African Union 2016a, para. 7; Assembly of ICC States Parties 2013b). Only a modest change to the Rules of Procedure and Evidence has been adopted, in response to Kenyan government efforts to have Kenyatta and Ruto excused from constant attendance at trial, so as to allow them to conduct their official duties (Assembly of ICC States Parties 2013a; Hobbs 2015, 88-95). The direct impact of this minor rule change on ICC operations has been limited. But the political consequences of the amendments debate are more substantial, as the resistance from the majority of ICC members spurred further anger towards the Court among Kenya and its allies.

A second, and related, form of institutional change extends the jurisdiction of the African Court of Justice and Human and Peoples' Rights to international crimes, including those under ICC jurisdiction (Assembly of the African Union 2014, 18-25). In one sense this can be interpreted as an expansion of international criminal accountability through the creation of a new regional judicial body that will both increase institutional capacity and may prove more palatable to African states wary of the ICC's current operations. In this respect, the African Court could serve as an intermediary level in the complementarity relationship between the Court and states, and thus further improve the international response to atrocity. Yet the mandate of the African Court also presents a direct challenge to the ICC's norm of individual criminal accountability in that it explicitly exempts sitting Heads of State and Government from its jurisdiction (Assembly of the African Union 2014, 38-39). 


\section{Non-compliance and the international community's response}

In light of the above objections, the AU has expended a great deal of diplomatic energy in cultivating a perception of regional solidarity and urging its members to "adhere and articulate commonly agreed positions in line with their obligations under the Constitutive Act of the African Union" (Assembly of the African Union 2016a, para. 11.i). Most provocatively, this has involved a demand that AU members refuse to arrest and surrender Bashir or cooperate with the ICC processes concerning Kenyatta and Ruto (Assembly of the African Union 2009, para. 10, 2016a, para. 2.iv) These developments pose a substantial challenge to the authority of the Court, since they create a conflict between two inter-governmental organizations to which many states share overlapping obligations.

President Bashir has made at least 75 trips to more than 20 countries-including ICC State Parties like Chad, Jordan, Kenya, South Africa, and Uganda-in defiance of the arrest warrants (All Africa 2016). These episodes have generated a wealth of claims between the ICC and $\mathrm{AU}$ and its affected states that highlight the interaction of behavior and discourse. They are, moreover, indicative of a genuine interpretive dilemma between potentially conflicting legal rules. A number of governments contend that Head of State immunity continues to apply with respect to ICC non-parties and they are consequently prevented from acting on the Bashir arrest warrant (ICC Pre-Trial Chamber I 2011a, 7; ICC Pre-Trial Chamber II 2013; ICC Registrar 2014, sec. III(2)). The Pre-Trial Chamber has repeatedly ruled that immunity not applicable under international courts and consequently that Article 98 does not bar ICC State Parties from surrendering President Bashir to the Court (ICC Pre-Trial Chamber II 2015b, para. 9). ${ }^{10}$ In response, the AU has requested that the ICC Assembly of States Parties examine the issue and has further sought an International Court of Justice advisory opinion concerning the status of immunities and the obligation of states under international law, with specific reference made to the interaction of Articles 27 and 98 (Assembly of the African Union 2018, paras. 5(iii)).

AU members such as Chad, the DRC, and South Africa have further justified their refusal to arrest President Bashir by asserting that their legal obligations to the African Union supersede those to the International Criminal Court (ICC Pre-Trial Chamber I 2011b, 5; ICC Pre-Trial Chamber II 2015b, para. 4). The AU subsequently commended these states for their

\footnotetext{
10 The PTC's rulings have been criticized by some scholars, and there is a lively debate on this question. Interested readers can compare, for example, submitted observations from legal academics concerning the PreTrial Chamber's finding of non-compliance with respect to Jordan: https:/www.icc-cpi.int/Pages/crmrefined.aspx? situation=ICC-02/05.
} 
fidelity to AU Decisions regarding non-cooperation (Assembly of the African Union 2015, para. 18, 2016a, para. 3). Some African ICC members-notably Kenya, South Africa and Uganda - that had previously made public commitments to arrest Bashir have more recently reversed their position, suggesting a growing challenge to the idea of universal accountability (Vilmer 2016, 1325). Responses within and outside Africa are not monolithic, however. Concerted civil society advocacy has kept pressure on governments resulting in a number of instances where President Bashir has cancelled or shortened his foreign visits in order to avoid threatened arrest (Coalition for the International Criminal Court 2010, 1 and 3, 2015, 9). Forceful statements from the AU also mask considerable ambivalence among African states concerning ICC interventions in Sudan, Kenya, and elsewhere (Mills 2012, 431). Yet the prevailing pattern of discourse suggests that many states continue to resist the application of the non-impunity norm to sitting Heads of State.

Bashir's 2015 visit to South Africa is emblematic of this tension. The welcoming of an ICC fugitive by a prominent member state-and formerly key ICC proponent - seems especially damaging to the authority of the ICC and legitimacy of the non-impunity norm. Mirroring the justifications identified above, the ANC government argued that Bashir was protected by a legal immunity from arrest as he was travelling as Head of State to an official AU event; South Africa was therefore faced with competing obligations that existing international law could not definitively resolve (ICC Pre-Trial Chamber II 2015b, para. 4). ${ }^{11}$ The Supreme Court of South Africa was highly critical of the visit and sought to compel the government to hold Bashir pending its ultimate determination that he was indeed subject to arrest and surrender under ICC jurisdiction. The government defied this order, however, and facilitated Bashir's surreptitious departure from South Africa from a military airfield.

On 9 March 2015, the ICC formally issued a finding of non-compliance against the Government of Sudan for its failure to arrest and surrender President Bashir, and transmitted this finding to the Security Council for prospective punishment (ICC Pre-Trial Chamber II 2015a). The Court has found a further seven State Parties - Chad, DRC, Djibouti, Jordan, Malawi, South Africa, and Uganda - to be similarly in violation of their obligations and (with the exception of South Africa) referred their situations to the Security Council and Assembly of States Parties for further consideration. Despite general exhortations towards improving cooperation, no punishments have been enacted - or even seriously considered (Assembly of

\footnotetext{
${ }^{11}$ Detailed discussion of the South African episode can be found in the recent symposium in the Journal of International Criminal Justice 13(5) (2015).
} 
ICC States Parties 2017). Supporters of the Bashir indictment regard the ICC as a useful tool in stigmatizing the Sudanese regime, and have made repeated public calls for the arrest warrant to be enforced. Yet these same actors have been unwilling to deploy more direct coercionsuch as the denial of aid or imposition of sanctions - to compel Sudan or implicated states to hand over Bashir. This has led the ICC Prosecutor to suspend investigations in Darfur due to inaction, and arguably active interference, from the international community.

The Kenyatta and Ruto cases further this trend. Kenyan officials have repeatedly levelled public accusations of an "unaccountable ICC prosecutor - with a political axe to grind" and the specter of a "politicized prosecution" (Republic of Kenya 2013, 1-2, 4, 9-11). This led to a vote by the Kenyan Parliament in September 2013 to withdraw from the Rome Statute - a process that remains unrealized. The Kenyan government also suspended cooperation relating to witnesses and the provision of evidence which "has prevented the Court from exercising its functions and power under the Statute." (ICC Trial Chamber V(B) 2016, para. 26) This belligerent strategy has paid off. In an act that mimics the Sudan experience, the ICC Prosecutor announced on 5 December 2014 that she was withdrawing charges against President Kenyatta, citing the inability to access evidence and insufficient state cooperation to support a successful prosecution. $^{12}$

The Bashir and Kenyatta cases raise profound questions concerning the extent of the international community's commitment to non-impunity. Civil society groups have regularly called for greater efforts in upholding ICC requests with respect to Sudan and Kenya, thus far to little avail (Amnesty International 2012; Kenyans for Peace With Truth and Justice 2014). Yet while dramatic, non-compliance has also sown seeds of potential norm reinforcement via domestic and international legal processes. For example, ICC officials maintained an ongoing dialogue with their South African counterparts during and since Bashir's visit, with these discussions extensively focusing on the relevant legal issues (Assembly of ICC States Parties 2015b, para. 14 and 28-33; ICC Pre-Trial Chamber II 2015b). In 2016 the South African Supreme Court of Appeal decided in a unanimous judgement that the government had violated its obligations under the national and international law - a finding that was reinforced by the ICC Pre-Trial Chamber in July 2017 (The Supreme Court of Appeal of South Africa 2016; ICC Pre-Trial Chamber II 2017, 44). It is also notable that the incident generated a great deal of media attention which local and transnational civil society were keen to exploit as evidence of

\footnotetext{
12 On 13 March 2015, Trial Chamber V(B) terminated the proceedings against Mr. Kenyatta (International Criminal Court 2015). The charges against Mr. Ruto were also subsequently vacated.
} 
democratic backsliding by the Zuma government. Some states and the Court itself have also criticized South Africa's inaction, specifically challenging the assertion that customary international law or AU solidarity override ICC obligations (Assembly of ICC States Parties 2015a; ICC Pre-Trial Chamber II 2015b).

\section{Reversing the tide? The rise and (apparent) demise of the mass-withdrawal threat}

Anger at the perceived indifference of the ICC and international community recently culminated in a proposal for African states to withdraw en masse from the Rome Statute (Assembly of the African Union 2016a, para. 10.iv; African Union 2017). The AU process followed in the wake of announcements by Burundi, South Africa, and The Gambia that they would be leaving the ICC, leading to well-founded concerns for a major rejection of the Court. Withdrawals from international treaties are rare, and such actions would thus prove especially damaging to the status of the ICC and non-impunity norm. This is especially true of South Africa which, as a comparatively stable democracy and former ICC champion, has been widely regarded as a bellwether of human rights in Africa.

Yet because of its public nature, the mass withdrawal threat has also served as a platform for actors to reiterate their commitment to non-impunity. A number of governments including Nigeria and Senegal opposed the AU bill and there has been widespread resistance among domestic human rights groups and national media in countries like Kenya (Keppler 2017; Daily Nation 2016; Jo and Simmons, this issue). In Zambia, for example, a recent national consultative process found that over $91 \%$ of respondents opposed ICC withdrawal (Namaiko 2017). At the ICC Assembly of States Parties meeting in December 2016, "[t]he vast majority of African states-including Burkina Faso, Botswana, Democratic Republic of Congo, Côte d'Ivoire, Lesotho, Malawi, Mali, Namibia, Nigeria, Senegal, Sierra Leone, Tanzania, Uganda and Zambia — reaffirmed their desire to stay part of the Rome Statute system and work for positive reform of the ICC." (Coalition for the International Criminal Court 2016) In the face of this discursive support, the anticipated wave of withdrawals has not materialized.

These diplomatic efforts have been bolstered by concerted pressure which appears to have stalled or reversed existing domestic withdrawal efforts. Civil society groups have particularly targeted South Africa — such as with the CICC's petition under the tag-line "What would Mandela do?"13 _ in a coordinated campaign that explicitly invokes international legal accountability and ICC obligations (Amnesty International 2017). In an episode that mirrors

\footnotetext{
${ }^{13}$ http://coalitionfortheicc.org/south-africa-stay-icc.
} 
the experience of President Bashir's visit, the high court in Pretoria invalidated South Africa's withdrawal on the grounds that the process did not conform to constitutional requirements; the judgement determined that the South African parliament would have to vote on a repeal bill, a process that will substantially complicate and delay any prospective withdrawal (Allison 2017). In February 2017, The Gambia's new democratically-elected leader, Adama Barrow, announced that he had reversed his country's withdrawal as a demonstration of renewed commitment to human rights and international cooperation (Saine and Jahateh 2017).

\section{Conclusion}

The emergence of the ICC did not single-handedly transform international opinion regarding non-impunity, but rather intensified an existing schism between increasing demands for universal criminal accountability and traditional understandings of state sovereignty and noninterference. The principal empirical measures thus reveal a mixed picture of norm status. Discursive endorsement (validity) is pervasive, as most states as well as the vast majority of civil society and the Court itself have rhetorically upheld the legitimacy of criminal accountability; the most common challenges have instead focused on modifications to the norm's scope. Yet behavioral support for the norm (facticity) has been notably lacking in key instances as states have proven unwilling to counteract persistent non-compliance with respect to Sudan and Kenya. This inconsistency has clearly impeded the ability of the Court to realize its justice mandate and has created political space in which exemptions to international legal jurisdiction may become normalized again. When considered in its global context, however, the evidence suggests that the non-impunity norm has not been substantially eroded even as the ICC has come under sustained assault. At the present moment, the norm as embodied in the Rome Statute has not been supplanted by its most obvious alternatives, either in the form of the prior norm that exempted senior state officials from international accountability or a broader diminishment of criminal sanction as the default response to atrocity.

This article largely affirms the central conjectures of the framework paper. First, actors matter, as the effects of contestation have been counteracted by the diversity of the pro-ICC constituency. Despite the AU's efforts at projecting an aura of regional cohesion, views within Africa are less uniformly antagonistic than is often suggested. And while the international community as a whole has failed to punish non-compliance-weakening the norm in terms of its behavioral effects - it has generally been unreceptive to most discursive challenges. Power imbalances in the international system, as manifest in the United Nations Security Council and Assembly of States Parties, have been utilized to resist the formal weakening of the non- 
impunity norm via permanent exemptions, despite the apparent hypocrisy this sometimes entails.

Second, I concur that applicatory contestation is typically less damaging to norm robustness than forms of validity contestation. Some African states have challenged the legitimacy of the ICC as fundamentally unfair and excessively homogenous in its requirement for criminal sanction. But while such claims have generated a good deal of public attention, they have not been accepted beyond already like-minded sceptics. The more viable strategy has been to attempt to constrain the practical effects of the non-impunity norm. This has exposed enduring disagreements regarding the scope of international accountability but has not led to substantial norm erosion, principally because the debates have taken place on the discursive and procedural terrain of the Rome Statute and associated international law. Efforts at enshrining an explicit recognition of immunity for sitting Heads of State have not been widely endorsed beyond the African regional grouping. However, applicatory contestation that becomes a permanent feature of diplomacy is a more substantial threat to norm robustness. An enduring failure of the international community to enforce compliance with ICC requests remains the most likely avenue by which the non-impunity norm may be altered to include a de facto exemption for senior political leaders.

Finally, the expectation that legalization of norms will guard against their weakening is confirmed but requires more nuance: the shift into a legal mode does shape and constrain the conduct of contestation but international law provides a linguistic structure that can be deployed in the service of diverse objectives. The Bashir and Kenyatta cases demonstrate that legal argumentation need not always support a particular outcome when plausible competing interpretations of a norm exist. Institutionalization, in other words, cuts both ways: the architecture of the international legal system has offered alternative sources of justification for ICC critics to advance a conception of the non-impunity norm in which senior political leaders retain specific exemptions from international criminal jurisdiction and has provided the means by which supporters of the ICC have countered this contestation.

Constructivist research has made clear that actors make and re-make norms through their actions, which leaves space for social understandings to wax and wane over time. Much therefore depends on how (non)compliance and discursive justifications interact in the coming years to shape the collective understanding of the limits of non-impunity - and specifically whether an exception for senior state officials becomes enshrined in international practice. Should the forms of contestation discussed above continue, the ambitions of the Rome Statute to transform international criminal justice by making all individuals subject to the law would 
be called into doubt. Yet the international community possesses the means of reinforcing its stated commitment to an equal and impartial application of criminal accountability, should it wish to do so. 


\section{References}

AFP. 2008. "Rwandan President Says ICC Targeting African Countries." Sudan Tribune, August 1, 2008. http://www.sudantribune.com/spip.php?article28103.

African Union. 2017. "Withdrawal Strategy Document - Draft 2." African Union. https://www.hrw.org/sites/default/files/supporting_resources/icc_withdrawal_strategy jan._2017.pdf.

African Union Peace and Security Council. 2009. "Communiqué of the 175th Meeting of the Peace and Security Council.” PSC/PR/Comm.(CLXXV)Rev.1. Addis Ababa, Ethiopia: African Union. http://www.peaceau.org/uploads/iccarrestwarranteng.pdf.

Akande, Dapo. 2009. "The Legal Nature of Security Council Referrals to the ICC and Its Impact on Al Bashir's Immunities." Journal of International Criminal Justice 7 (2): 333-52.

All Africa. 2016. "Sudan: 75 Trips to 22 Countries in 7 Years - an Indicted War Criminal's Travels." http://allafrica.com/stories/201603071669.html.

Allison, Simon. 2017. "THINK AGAIN: The ICC Can Bring South Africa Back into the Fold.” Institute for Security Studies. https://issafrica.org/iss-today/think-again-the-icccan-bring-south-africa-back-into-the-fold.

Amnesty International. 2012. "Letter from African Civil Society Organizations to Justice Ministers and Attorneys General from African States Parties to the International Criminal Court (AFR 01/007/2012)," May 3, 2012. http://www.amnesty.org/en/library/info/AFR01/007/2012/en. - 2017. "Briefing Submitted to the Portfolio Committee on Justice and Correctional Services in Response to the Call for Public Comment on the Proposed Implementation of the Rome Statute of the International Criminal Court Repeal Bill (The Repeal Bill)." London: Amnesty International. https://www.amnesty.org/en/documents/afr01/5844/2017/en/.

Appeals Chamber, International Criminal Court. 2011. "Decision on the Admissibility of the 'Appeal of the Government of Kenya against the "Decision on the Request for Assistance Submitted on Behalf of the Government of the Republic of Kenya Pursuant to Article 93(10) of the Statute and Rule 194 of the Rules of Procedure and Evidence."" ICC-01/09-78. The Hague, Netherlands: International Criminal Court. https://www.icc-cpi.int/CourtRecords/CR2011_12079.PDF.

Assembly of ICC States Parties. 2013a. "Amendments to the Rules of Procedure and Evidence.” Resolution ICC-ASP/12/Res.7. The Hague, Netherlands: International Criminal Court. http://asp.icc-cpi.int/iccdocs/asp_docs/Resolutions/ASP12/ICC-ASP12-Res7-ENG.pdf.

. 2013b. "Special Segment as Requested by the African Union: 'Indictment of Sitting Heads of State and Government and Its Consequences on Peace and Stability and Reconciliation' (ICC-ASP/12/61)." Assembly of States Parties to the Rome Statute of the International Criminal Court. https://www.icccpi.int/iccdocs/asp_docs/ASP12/ICC-ASP-12-61-ENG.pdf. . 2014a. "Report of the Working Group on Amendments." ICC-ASP/13/31. New York: Thirteenth Assembly of States Parties to the International Criminal Court. https://asp.icc-cpi.int/iccdocs/asp_docs/ASP13/ICC-ASP-13-31-ENG.pdf. . 2014b. "Report of the Working Group on Amendments Annex I: Informal Compilation of Proposals to Amend the Rome Statute." ICC-ASP/13/31. New York: Thirteenth Assembly of States Parties to the International Criminal Court. https://asp.icc-cpi.int/iccdocs/asp_docs/ASP13/ICC-ASP-13-31-ENG.pdf. 
2015a. "Press Release: The President of the Assembly Calls on States Parties to Fulfill Their Obligations to Execute the Arrest Warrants against Mr. Al Bashir." International Criminal Court. https://www.icccpi.int/en_menus/icc/press\%20and\%20media/press\%20releases/Pages/pr1117.aspx. . 2015b. "Report of the Bureau on Non-Cooperation." ICC-ASP/14/38. The Hague: International Criminal Court. https://asp.icc-cpi.int/iccdocs/asp_docs/ASP14/ICCASP-14-38-ENG.pdf.

. 2017. "Report of the Bureau on Non-Cooperation." ICC-ASP/16/36. New York: International Criminal Court. https://asp.icc-cpi.int/iccdocs/asp_docs/ASP16/ICCASP-16-36-ENG.pdf.

Assembly of the African Union. 2009. "Decision on the Meeting of African States Parties to the Rome Statute of the International Criminal Tribunal (ICC)."

Assembly/AU/Dec.245(XIII) Rev.1. Sitre, Libya: African Union Thirteenth Ordinary Session. http://www.au.int/en/sites/default/files/decisions/9560-

assembly_en_1_3_july_2009_auc_thirteenth_ordinary_session_decisions_declaration s_message_congratulations_motion_0.pdf.

. 2011. "Decision on the Implementation of the Decisions of the International Criminal Court." EX.CL/639(XVIII). Addis Ababa, Ethiopia: African Union Sixteenth Ordinary Session. http://www.au.int/en/sites/default/files/decisions/9645assembly_en_30_31_january_2011_auc_assembly_africa.pdf.

. 2012. "Decision on the Progress Report of the Commission on the Implementation of the Assembly Decisions on the International Criminal Court (ICC) - Doc.

EX.CL/710(XX)." Assembly/AU/Dec.397(XVIII). Addis Ababa, Ethiopia: African Union Eighteenth Ordinary Session.

http://www.au.int/en/sites/default/files/decisions/9649-assembly_au_dec_391_415_xviii_e.pdf.

2013. "Decision on Africa's Relationship With the International Criminal Court (ICC)." Ext/Assembly/AU/Dec.1. Addis Ababa, Ethiopia: Extraordinary Session of the Assembly of the African Union.

http://www.au.int/en/sites/default/files/decisions/9655-

ext_assembly_au_dec_decl_e_0.pdf.

. 2014. "Protocol on Amendments to the Protocol on the Statute of the African Court of Justice and Human Rights." African Union.

http://archive.au.int/collect/charters/import/English/AMENDMENTS\%20PROTOCO L\%20AFRICAN\%20COURT_E.pdf.

2015. "Decision on the Progress Report of the Commission on the Implementation of Previous Decisions on the International Criminal Court." Assembly/AU/18(XXIV). Addis Ababa, Ethiopia: African Union Twenty-Fourth Ordinary Session.

http://www.au.int/en/sites/default/files/decisions/9665-assembly_au_dec_546_568_xxiv_e.pdf.

2016a. "Decision on the International Criminal Court - Doc. EX.CL/952(XXVIII)." Assembly/AU/Dec.590(XXVI). Addis Ababa, Ethiopia: African Union Twenty-Sixth Ordinary Session. http://www.au.int/en/sites/default/files/decisions/29514assembly_au_dec_588___604_xxvi_e.pdf.

. 2016b. "Decision on the International Criminal Court." EX.CL/987(XXIX). Kigali, Rwanda: African Union Twenty-Seventh Ordinary Session.

http://www.au.int/en/sites/default/files/decisions/31274-assembly_au_dec_605620_xxvii_e.pdf.

2018. "Decision on the International Criminal Court - Doc. EX.CL/1068(XXXII)." Assembly/AU/Dec.672(XXX). Addis Ababa, Ethiopia: African Union Thirtieth 
Ordinary Session. https://au.int/sites/default/files/decisions/33908assembly_decisions_665_-_689_e.pdf.

Bosco, David. 2014. Rough Justice: The International Criminal Court's Battle to Fix the World, One Prosecution at a Time. Oxford; New York: Oxford University Press.

Bower, Adam. 2017. Norms Without the Great Powers: International Law and Changing Social Standards in World Politics. Oxford: Oxford University Press.

Brunnée, Jutta, and Stephen J. Toope. 2010. Legitimacy and Legality in International Law: An Interactional Account. Cambridge; New York: Cambridge University Press.

Clarke, Kamari Maxine, Abel S. Knottnerus, and Eefje de Volder, eds. 2016. Africa and the ICC: Perceptions of Justice. New York: Cambridge University Press.

Coalition for the International Criminal Court. 2010. "African Civil Society Stands Up for Justice." Africa Update, no. 14 (October).

http://www.coalitionfortheicc.org/documents/AfricaUpdate14_eng.pdf.

. 2015. "The Global Justice Monitor." 47. The Hague: Coalition for the International Criminal Court.

http://www.coalitionfortheicc.org/documents/Monitor_47_English.pdf. - 2016. "Annual ICC Assembly: States Hold Ground on ICC, but Serious Challenges Remain | Coalition for the International Criminal Court." December 5, 2016. http://www.coalitionfortheicc.org/news/20161205/annual-icc-assembly-states-holdground-icc-serious-challenges-remain.

Daily Nation. 2016. "Leaving ICC Is Not an Option for Africa," January 31, 2016. http://www.nation.co.ke/oped/Editorial/-Leaving--ICC-/-/440804/3055908/-/7lhjgl//index.html.

Drumbl, Mark A. 2007. Atrocity, Punishment, and International Law. Cambridge; New York: Cambridge University Press.

Federal Republic of Nigeria. 2013. "Statement by the Leader of Delegation Mr. Mohanned Bello Adoke, SAN, CFR, Honourable Attorney General of the Federation and Minister of Justice." presented at the Twelfth Assembly of States Parties of the Rome Statute of the International Criminal Court, The Hague, Netherlands, November 21. https://asp.icc-cpi.int/iccdocs/asp_docs/ASP12/GenDeba/ICC-ASP12-GenDebaNigeria-ENG.pdf.

Gaeta, Paola. 2009. "Does President A1 Bashir Enjoy Immunity from Arrest?” Journal of International Criminal Justice 7 (2): 315-32.

Hobbs, Patricia. 2015. "Contemporary Challenges in Relation to the Prosecution of Senior State Officials before the International Criminal Court." International Criminal Law Review 15: 76-100.

ICC Pre-Trial Chamber I. 2011a. "Decision Pursuant to Article 87(7) of the Rome Statute on the Failure by the Republic of Malawi to Comply with the Cooperation Requests Issued by the Court with Respect to the Arrest and Surrender of Omar Hassan Ahmad Al Bashir." ICC-02/05-01/09. The Hague: International Criminal Court. https://www.icc-cpi.int/iccdocs/doc/doc1287184.pdf. - 2011b. "Decision Pursuant to Article 87(7) of the Rome Statute on the Refusal of the Republic of Chad to Comply with the Cooperation Requests Issued by the Court with Respect to the Arrest and Surrender of Omar Hassan Ahmad Al Bashir." ICC-02/0501/09. The Hague, Netherlands: International Criminal Court. http://www.icccpi.int/iccdocs/doc/doc1384955.pdf.

ICC Pre-Trial Chamber II. 2010. "Decision Pursuant to Article 15 of the Rome Statute on the Authorization of an Investigation into the Situation in the Republic of Kenya." ICC01/09. The Hague, Netherlands: International Criminal Court. http://www.icccpi.int/iccdocs/doc/doc854287.pdf. 
2013. "Report of the Registry on the Observations Submitted by the Republic of Chad on Omar Al-Bashir's Visit to the Republic of Chad - Annex 1: Observations of the Republic of Chad." The Hague: International Criminal Court. https://www.icccpi.int/iccdocs/doc/doc1570946.pdf\#search=ICC\%2D02\%2F05\%2D01\%2F09\%2D15 0 .

. 2015a. "Decision on the Prosecutor's Request for a Finding of Non-Compliance Against the Republic of the Sudan." ICC-02/05-01/09. The Hague, Netherlands: International Criminal Court. http://www.icc-cpi.int/iccdocs/doc/doc1919142.pdf. 2015b. "Decision Following the Prosecutor's Request for an Order Further Clarifying That the Republic of South Africa Is under the Obligation to Immediately Arrest and Surrender Omar A1 Bashir (ICC-02/05-01/09)." ICC-02/05-01/09. The Hague: International Criminal Court. https://www.icccpi.int/CourtRecords/CR2015_06500.PDF.

. 2017. "Decision under Article 87(7) of the Rome Statute on the Non-Compliance by South Africa with the Request by the Court for the Arrest and Surrender of Omar AlBashir." ICC-02/05-01/09. The Hague: International Criminal Court. https://www.icccpi.int/CourtRecords/CR2017_04402.PDF.

ICC Registrar. 2014. "Transmission to Pre-Trial Chamber II of the Observations Submitted by the Democratic Republic of Congo Pursuant to the 'Decision Requesting Observations on Omar Al-Bashir's Visit to the Democratic Republic of Congo' Dated 3 March 2014. Annex 2 Public.” ICC-02/05-01/09-190-AnxII. The Hague, Netherlands: International Criminal Court. https://www.icccpi.int/CourtRecords/CR2014_02813.PDF.

ICC Trial Chamber V(B). 2016. "Second Decision on Prosecution's Application for a Finding of Non-Compliance under Article 87(7) of the Statute." ICC-01/09-02/11. The Hague: International Criminal Court. https://www.icccpi.int/CourtRecords/CR2016_06654.PDF.

International Criminal Court. 2015. "Press Release: Trial Chamber V(B) Terminates the Proceedings (ICC-CPI-20150313-PR1099).” http://www.icccpi.int/en_menus/icc/press\%20and\%20media/press\%20releases/Pages/pr1099.aspx.

Jalloh, Charles Chernor, Dapo Akande, and Max du Plessis. 2011. "Assessing the African Union Concerns about Article 16 of the Rome Statute of the International Criminal Court." African Journal of Legal Studies 4 (1): 5-50.

Jalloh, Charles Chernor, and Ilias Bantekas, eds. 2017. The International Criminal Court and Africa. Oxford, New York: Oxford University Press.

Kelley, Judith. 2007. "Who Keeps International Commitments and Why? The International Criminal Court and Bilateral Nonsurrender Agreements." The American Political Science Review 101 (3): 573-89.

Kendall, Sara. 2014. "'UhuRuto' and Other Leviathans: The International Criminal Court and the Kenyan Political Order." African Journal of Legal Studies 7 (3): 399-427.

Kenyans for Peace With Truth and Justice. 2014. "Statement by the Kenyans for Peace With Truth and Justice." presented at the Thirteenth Assembly of States Parties of the Rome Statute of the International Criminal Court, New York, December 12. https://asp.icc-cpi.int/iccdocs/asp_docs/ASP13/GenDeba/ICC-ASP13-GenDebaKPTJ-ENG.pdf.

Keppler, Elise. 2017. “AU's 'ICC Withdrawal Strategy' Less than Meets the Eye.” Human Rights Watch. February 1, 2017. https://www.hrw.org/news/2017/02/01/aus-iccwithdrawal-strategy-less-meets-eye.

Kersten, Mark. 2018. "Building Bridges and Reaching Compromise: Constructive Engagement in the Africa-ICC Relationship." Berlin: Wayamo Foundation. 
http://www.wayamo.com/archives/policy-paper-africa-and-the-icc-building-bridgesand-reaching-compromise/.

Kirgis, Frederic L. 1987. "Custom on a Sliding Scale." The American Journal of International Law 81 (1): 146-51.

Knottnerus, Abel S. 2016. "The AU, the ICC, and the Prosecution of African Presidents." In Africa and the ICC: Perceptions of Justice, edited by Kamari Maxine Clarke, Abel S. Knottnerus, and Eefje de Volder, 152-84. New York: Cambridge University Press.

Mills, Kurt. 2012. "Bashir Is Dividing Us': Africa and the International Criminal Court." Human Rights Quarterly 34 (2): 404-47.

Mills, Kurt, and Alan Bloomfield. 2018. "African Resistance to the International Criminal Court: Halting the Advance of the Anti-Impunity Norm." Review of International Studies 44 (1): 101-27.

Murungu, Chacha, and Japhet Biegon, eds. 2011. Prosecuting International Crimes in Africa. Pretoria, South Africa: Pretoria University Law Press.

Namaiko, Chila. 2017. “Zambia: 'We Stay in ICC.” Times of Zambia, July 1, 2017. http://allafrica.com/stories/201707010076.html.

People's Republic of China. 2014. "Statement by Mr. MA Xinmin, Deputy Director-General of the Department of Treaty and Law of the Ministry of Foreign Affairs." presented at the Thirteenth Assembly of States Parties of the Rome Statute of the International Criminal Court, New York, December 8. http://asp.icccpi.int/iccdocs/asp_docs/ASP13/GenDeba/ICC-ASP13-GenDeba-China-ENG.pdf.

Plessis, Max du. 2010. The International Criminal Court That Africa Wants. ISS Monograph No. 172. Pretoria, South Africa: Institute for Security Studies. http://www.issafrica.org/anicj/uploads/Du_Plessis_The_ICC_that_Africa_wants.pdf.

Price, Richard. 2006. "Detecting Ideas and Their Effects." In The Oxford Handbook of Contextual Political Analysis, edited by Robert E. Goodwin and Charles Tilly, 25265. Oxford; New York: Oxford University Press.

Republic of Kenya. 2011. "Application on Behalf of the Government of The Republic of Kenya Pursuant to Article 19 of the ICC Statute (ICC-01/09-01/11-19)." http://www.icc-cpi.int/iccdocs/doc/doc1050005.pdf. . 2013. "Aide Memoire: Kenya and the International Criminal Court." http://www.coalitionfortheicc.org/documents/AIDE_MEMORIE_KENYA_ICC_(2).p df.

Reus-Smit, Christian, ed. 2004. The Politics of International Law. Cambridge: Cambridge University Press.

Rome Statute of the International Criminal Court. 1998. https://www.icc-cpi.int/resourcelibrary/Documents/RS-Eng.pdf.

Russian Federation. 2014. "Statement of the Russian Federation Delivered by Ms. Diana Eloeva, First Secretary of the Legal Department of the Ministry of Foreign Affaires." presented at the Thirteenth Assembly of States Parties of the Rome Statute of the International Criminal Court, New York, December 12. http://asp.icccpi.int/iccdocs/asp_docs/ASP13/GenDeba/ICC-ASP13-GenDeba-Russian-ENG.pdf.

Saine, Pap, and Lamin Jahateh. 2017. "Gambia Announces Plans to Stay in International Criminal Court.” Reuters. https://www.reuters.com/article/us-gambia-justice-iccidUSKBN15S2HF.

Schabas, William A. 2017. An Introduction to the International Criminal Court. 5th ed. Cambridge: Cambridge University Press.

Scott, Shirley V. 1994. "International Law as Ideology: Theorizing the Relationship between International Law and International Politics." European Journal of International Law 5 (1): 313-25. 
Sikkink, Kathryn. 2011. The Justice Cascade: How Human Rights Prosecutions Are Changing World Politics. New York: W. W. Norton \& Company.

Simons, Marlise, and Neil Macfarquhar. 2009. "Court Issues Arrest Warrant for Sudan's Leader." The New York Times, March 5, 2009, sec. International / Africa. http://www.nytimes.com/2009/03/05/world/africa/05court.html.

Stahn, Carsten, ed. 2015. The Law and Practice of the International Criminal Court. Oxford; New York: Oxford University Press.

Sudan Tribune. 2010. "AU Chief Challenges ICC to Arrest Sudanese President," July 23, 2010. http://www.sudantribune.com/spip.php?article35748.

The Supreme Court of Appeal of South Africa. 2016. "The Minister of Justice and Constitutional Development v The Southern African Litigation Centre (867/15) [2016] ZASCA 17." http://www.ejiltalk.org/wp-content/uploads/2016/03/BashirSouth-Africa-Supreme-Court.pdf.

Tiemessen, Alana. 2014. "The International Criminal Court and the Politics of Prosecutions." The International Journal of Human Rights 18 (4-5): 444-61.

United Nations Security Council. 2005. Resolution 1593. http://www.un.org/en/ga/search/view_doc.asp?symbol=S/RES/1593\%20(2005). 2013. Agenda Item: Peace and Security in Africa. New York. http://www.un.org/en/ga/search/view_doc.asp?symbol=S/PV.7060.

Vilmer, Jean-Baptiste Jeangène. 2016. "The African Union and the International Criminal Court: Counteracting the Crisis." International Affairs 92 (6): 1319-42.

Wiener, Antje. 2008. The Invisible Constitution of Politics: Contested Norms and International Encounters. Cambridge: Cambridge University Press. 